\title{
FLUORESCENCE DETECTED MAGNETIC RESONANCE (FDMR) SPECTROSCOPY OF CHLOROPHYLL-PROTEINS FROM BARLEY
}

\author{
by
}

\author{
GEOFF F. W. SEARLE', ROB B. M. KOEHORST ${ }^{1}$, TJEERD J. SCHAAFSMA ${ }^{1}$, \\ BIRGER LINDBERG MØLLER ${ }^{2}$ and DITER VON WETTSTEIN ${ }^{2}$
}

\author{
'Department of Molecular Physics, Agricultural University. \\ De Dreijen 11, NL 6703 BC Wageningen, The Netherlands. \\ 2Department of Physiology, Carlsberg Laboratory, \\ Gamle Carlsberg Vej 10, DK-2500 Copenhagen Valby
}

Keywords: Thylakoid proteins, optically detected magnetic resonance, excitation energy transfer, chlorophyll triplet state

\footnotetext{
Fluorescence detected magnetic resonance (FDMR) spectra and fluorescence emission spectra at $4.2 \mathrm{~K}$ of chlorophyll-proteins isolated and purified from barley thylakoids are presented. The FDMR spectra show the occurrence of chlorophyll $a$ triplet states in all five chlorophyll-proteins studied, namely $\mathrm{Chl}_{a}-\mathrm{P} 1, \mathrm{Chl}_{a}-\mathrm{P} 2, \mathrm{Chl}_{a}$ $\mathrm{P} 3, \mathrm{Chl}_{a / b}-\mathrm{Pl}$ and $\mathrm{Chl}_{a / b}-\mathrm{P} 2$.

The presence of more than one chlorophyll triplet each associated with a chlorophyll emitting at a specific wavelength gives rise to a characteristic wavelength dependence of the FDMR spectrum of chlorophyll-proteins. The zero field splitting parameters measured, combined with the observed fluorescence emission wavelengths suggest that three types of interactions of the $\mathrm{Mg}$ atom of chlorophyll $a$ occur in these proteins: a type similar to that in the parallel dimer $\left(\mathrm{Chl} a \cdot \mathrm{H}_{2} \mathrm{O}\right)_{2}$, seen at $721 \mathrm{~nm}$ for $\mathrm{Ch}_{a}$-PI leading to a positive FDMR signal; a type like that in $\mathrm{Chl} a \cdot 2$ pyridine also giving a positive FDMR signal, seen in $\mathrm{Chl}_{a}-\mathrm{P} 2$ and $\mathrm{Chl}_{a}-\mathrm{P} 3$; and a third type similar to that in $\mathrm{Chl} a \cdot 2 \mathrm{H}_{2} \mathrm{O}$ leading to a negative FDMR signal, seen for $\mathrm{Chl}_{a}-\mathrm{Pl}$ at $679 \mathrm{~nm}$, and for $\mathrm{Chl}_{a / b^{-}}$ $\mathrm{Pl}$ and $\mathrm{Ch}_{a / b}$-P2.

The FDMR spectrum in the antenna of photosystem I ( $\left.\mathrm{Chl}_{a}-\mathrm{Pl}\right)$ can probably be ascribed to that of a trap formed by a pair of interacting chlorophyll a molecules, indicating that the organisation of chlorophyll in the antenna may not in principle be very different from that in the photosystem I reaction centre, and that it contains approximately plane-parallel chlorophyll $a$ pairs. $\mathrm{Ch}_{a}-\mathrm{P} 2$ and $\mathrm{Chl}_{a}-\mathrm{P} 3$ do not show a long wavelength $(>700 \mathrm{~nm})$ emission, suggesting a much weaker interaction between chlorophyll molecules in these proteins compared to that in $\mathrm{Chl}_{a}-\mathrm{P} 1$. For $\mathrm{Chl}_{a / b}-\mathrm{Pl}$ and $\mathrm{Chl}_{a / b}-\mathrm{P} 2$ the absence of a long wavelength emission and the observation of zero field splitting (ZFS) parameters similar to that of monomeric $\mathrm{Chl} a \cdot 2 \mathrm{H}_{2} \mathrm{O}$ both indicate the absence of strong interactions between chlorophyll a molecules in these proteins also, and it is suggested that chlorophyll $a$ and chlorophyll $b$ molecules occur in interacting pairs.
} 


\section{INTRODUCTION}

Fluorescence detected magnetic resonance (FDMR) spectroscopy is a recent offspring of optically detected magnetic resonance (ODMR) spectroscopy, performed in a zero magnetic field $(8,9,26)$. Since a magnetic field is absent, there is no need to use oriented samples, such as single crystals, in order to obtain magnetic resonance spectra with satisfactory resolution $\left(\sim 10^{-2}\right)$. In addition, optical detection of magnetic resonance transitions is well-known to be very sensitive as compared with detection of microwave-absorption by diodes or bolometers, such as in conventional high-field electron paramagnetic resonance (EPR) spectroscopy (11). This combination of properties makes FDMR spectroscopy an ideal technique for studying complex systems, such as the chlorophyll-proteins of a photosynthetic membrane which can be obtained only in limited amounts and in non-oriented form.

Triplet state FDMR spectroscopy makes use of the fact, that the three-fold degeneracy of the molecular triplet state is lifted by spin-spin interaction, even in the absence of an external magnetic field. For photosynthetic pigments, the resulting zero field splittings (ZFS) are $\sim 10^{-2} \mathrm{~cm}^{-1}$. The energies of these non-degenerate triplet spin levels are denoted $\mathrm{X}, \mathrm{Y}$ and $\mathrm{Z}$ and are in the order $\mathrm{X}>\mathrm{Y}>\mathrm{Z}$, representing eigenvalues of the spin-Hamiltonian (31) of the triplet state.

Thus, the distances between the spin levels (zero-field splittings) are given by $\mathrm{X}-\mathrm{Y}, \mathrm{Y}-\mathrm{Z}$ and $X-Z$ in energy units. Conventionally these splittings are expressed in the parameters $D$ and E, related to $\mathrm{X}, \mathrm{Y}$ and $\mathrm{Z}$ by (31):

$$
\begin{aligned}
& D=-\frac{3}{2} Z \\
& E=-\frac{1}{2}(X-Y)
\end{aligned}
$$

The creation of a molecule in its lowest triplet state $T_{0}$ is usually obtained after optical excitation into an excited singlet state $S_{n}$, followed by intersystem crossing $S_{n} \rightarrow T_{0}$. Resonance transitions between the spin-levels of $T_{0}(X-Y, Y-Z$ and $\mathrm{X}-\mathrm{Z}$ ) can then in principle be detected as a change in the intensity of the phosphorescence of $T_{0}$, due to microwave absorption at any of the three resonance frequencies. Relaxation between $T_{0}$ spin levels is sufficiently slowed down at low temperatures (typically $\leqslant 4.2 \mathrm{~K}$ ) so that they can be considered as isolated. This is a necessary condition for observing FDMR spectra.

For photosynthetic pigments, phosphorescence is too weak (22) to be suitable for observing zero field magnetic resonance. However, the fluorescence intensity arising from $S_{l} \rightarrow S_{0}$ emission can be expressed as (3):

$$
I_{f}=A\left[N-\sum_{i=1}^{3} n_{i}\right]
$$

where $\mathrm{A}$ is an instrumental constant, $\mathrm{N}$ is the total number of pigment molecules and $\Sigma n_{i}$ represents the number of molecules in the spin levels of the lowest triplet state $\left(\mathrm{T}_{0}\right)$. It is assumed that the number of molecules in excited singlet states can be neglected under steady-state illumination of the sample.

It can be shown (3) that absorption of microwaves, resonant with any of the three zero field splittings of $T_{0}$, gives rise to a change of fluorescence $\Delta \mathrm{I}_{\mathrm{f}}$ given by

$$
\Delta I_{f}=A\left(k_{i}-k_{j}\right)\left(k_{i}+k_{j}\right)^{-1}\left(n_{i}^{o}-n_{j}^{o}\right)
$$

where $\mathrm{i} \neq \mathrm{j}=1,2,3$ and $\mathrm{n}_{\mathrm{i}, \mathrm{j}}^{\mathrm{j}}$ represents the steady state population of the $T_{0}$ spin levels $i$ or $j$ under continuous illumination and in the absence of microwaves; $k_{i, j}$ are the decay rate constants of these spin-levels. This equation shows that resonances may be observed only when $n_{i}^{o} \neq n_{j}^{0}$, and $k_{i} \neq k_{j}$. The last condition almost always holds for chlorophylls. The transition at $2 \mathrm{E}(=\mathrm{Y}-\mathrm{X})$ is often not observed since the top two spin-levels of $T_{0}$ accidentally have almost equal steady state populations.

For the observation of triplet states, the sensitivity of the FDMR technique compares favourably with the standard EPR techniques. Due to high values of fluorescence and triplet

Abbreviations: Chl $a=$ chlorophyll $a ; \mathrm{Chl} b=$ chlorophyll $b ; \mathrm{Chl}_{a}-\mathrm{P}=$ chlorophyll $a$-protein; $\mathrm{Chl}_{a} / b-\mathrm{P}=$ chlorophyll $a / b$-protein; EPR = electron paramagnetic resonance; FDMR = fluorescence detected magnetic resonance; $\mathrm{I}_{\mathrm{f}}=$ fluorescence intensity; $\mathrm{ODMR}=$ optically detected magnetic resonance; $\mathrm{SDS}=$ sodium dodecyl sulfate; ZFS = zero field splitting. 
yields of chlorophyll at low temperature a few micrograms of chlorophyll ( $a$ or $b$ ) in the chlorophyll-proteins are sufficient for observation. Under our experimental conditions resonance fluorescence changes of $\sim 0.1-1 \%$ are observed, corresponding to a relative change of $\sum n_{i}$ of $\sim 10 \%$.

FDMR spectroscopy has been shown to be a suitable method $(18,19,24,25)$ to probe the environment of chlorophyll molecules in the triplet state under in vitro conditions. In the present communication we describe the application of this technique on purified chlorophyllproteins which form integral parts of the photosynthetic membrane in higher plants. It is our aim to identify the way in which the chlorophylls are bound to their different apoproteins and to characterise chlorophyll-chlorophyll interactions from a comparison between FDMR parameters (ZFS values, signal sign) of chlorophyll in these proteins with those for various chlorophyll forms in vitro. The presence of chlorophyll in the triplet state arising from intersystem crossing can be expected in all chlorophyll-proteins at $4.2 \mathrm{~K}$ so long as triplet quenching processes are inhibited. A radical pair mechanism of chlorophyll triplet formation is possible in the chlorophyll-proteins containing active reaction centres $(4,14)$.

Recent advances in techniques for separation and isolation of chlorophyll-proteins from thylakoid membranes using detergent solubilisation followed by polyacrylamide gel electrophoresis have shown that virtually all chlorophyll is bound to specific proteins (21), and that there are in higher plants five different chlorophyllproteins: $\mathrm{Ch}_{a}-\mathrm{P} 1, \mathrm{Chl}_{a}-\mathrm{P} 2, \mathrm{Chl}_{a}-\mathrm{P} 3, \mathrm{Chl}_{a / b}-\mathrm{P} 1$ and $\mathrm{Ch}_{a / b}-\mathrm{P} 2$ (20). Polyacrylamide gel slices containing microgram quantities of individual chlorophyll-proteins form perfect objects for investigation by FDMR spectroscopy. Recently the groups of Hoff (13) and Clarke (6) have reported results obtained by FDMR on chloroplasts and a photosystem I fraction from chloroplasts; however these preparations still have a relatively complicated composition. A functionally undefined water-soluble chlorophyll $a / b$ protein from Atriplex hortensis has also been studied by Clarke, LeEnStra and Hagar (7). The present study combines FDMR spectroscopy and low temperature fluorescence spectro- scopy with the use of purified chlorophyllproteins from wild-type and mutant barley $(20$, 30 ). The mutant chlorina-f 2 is unable to form chlorophyll $b$ and therefore lacks in its thylakoids significant amounts of $\mathrm{Ch}_{a / b}-\mathrm{Pl}$ and $\mathrm{Chl}_{a / b}-\mathrm{P} 2$. Thus $\mathrm{Chl}_{a}-\mathrm{P} 1, \mathrm{Chl}_{a}-\mathrm{P} 2$ and $\mathrm{Chl}_{a}-\mathrm{P} 3$ can be studied in this mutant without the interference of chlorophyll $a / b$-proteins (20). Conversely, the mutant viridis $-2 b^{63}$ is deficient in $\mathrm{Ch}_{\alpha}-\mathrm{Pl}$ and therefore allows specific studies of the chlorophyll-proteins associated with photosystem II $(12,30)$.

\section{MATERIALS AND METHODS}

\subsection{Materials}

Purified thylakoids were prepared from wildtype, chlorina- $f 2$ and viridis- $z b^{63}$ barley leaves (Hordeum vulgare) according to the procedure described by Machold, Simpson and MølleR (20). The thylakoids were solublized in $1 \%$ sodium dodecyl sulfate using a SDS-chlorophyll ratio of 3.6:1. The dark-green supernatant obtained after ultracentrifugation was used immediately for SDS-polyacrylamide gel electrophoresis at $4{ }^{\circ} \mathrm{C}$ employing a Tris-sulfate buffer system (System IV in 20). After completion of electrophoresis the gels were inspected under visible and ultra-violet light and pieces of gel ( $1-2 \mathrm{~mm}$ wide and about $10 \mathrm{~mm}$ long) containing individual chlorophyll-proteins were cut out and immediately stored in stoppered vials in liquid $\mathrm{N}_{2}$.

\subsection{Methods}

All measurements have been carried out at 4.2 $\mathrm{K}$ using an FDMR-spectrometer, as previously described (3), with minor modifications. Samples, consisting of thin slices of gel material containing a single chlorophyll-protein, were placed in a thin-walled Teflon cup, fitting snugly around the bottom end of a $4 \mathrm{~mm}$ diameter quartz light pipe, which was lowered into liquid helium. No precautions were taken to avoid contact of the sample with air during this operation, since the presence of oxygen turns out not to affect the triplet state properties of chlorophyll under our experimental conditions.

The sample is surrounded by a few turns of a non-resonant helical slow wave structure, con- 
G. F. W. Searle et al.: FDMR of chlorophyll proteins

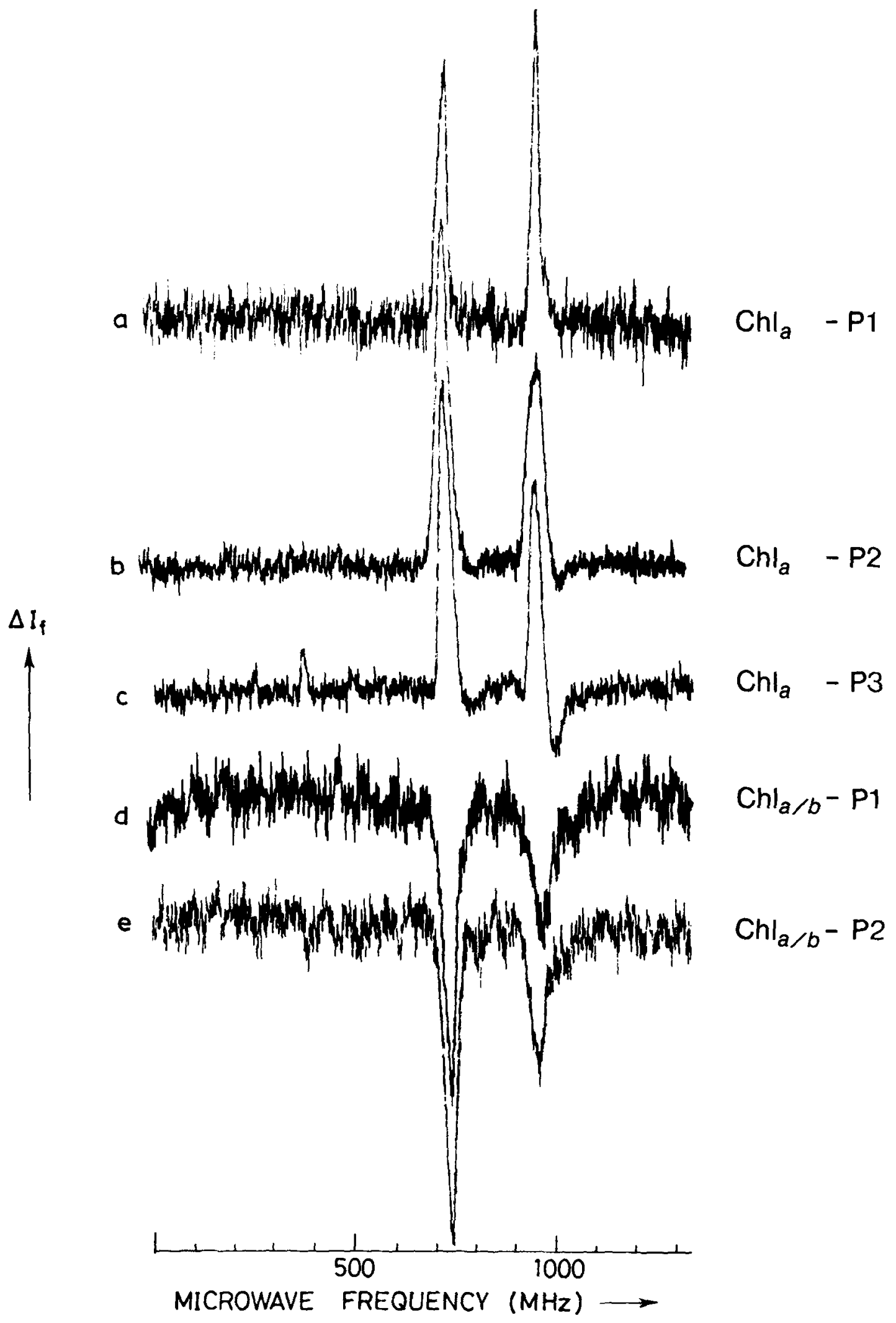

186

Carlsberg Res. Commun. Vol. 46, p. 183-194, 1981 
Figure 1. FDMR spectra of chlorophyll-proteins obtained from wild-type and mutant barley as indicated in Table I.

The change in fluorescence intensity ( $\Delta \mathbf{I}_{\mathrm{f}}$, arbitrary units) is caused by resonance transitions between the chlorophyll triplet spin levels using microwave radiation of constant power and variable frequency. Fluorescence detection wavelengths: a: $721 \mathrm{~nm}$; b-e: $686 \mathrm{~nm}$; detection bandwidth in all cases $10 \mathrm{~nm}$. Excitation source: Xe lamp with $\mathrm{CuSO}_{4}$ and Schott BG 12 filters. Emission detection: RCA 31034 photomultiplier cooled to $-40{ }^{\circ} \mathrm{C}$. Microwave sweep rate: $\sim 1000 \mathrm{MHz} / \mathrm{s}$, power $40 \mathrm{~mW}, T=4.2 \mathrm{~K}$. The FDMR spectra a-e in this Figure correspond to $4.2 \mathrm{~K}$ fluorescence spectra $\mathrm{a}-\mathrm{C}$ of Figure 2, i.e. Figures la and $2 \mathrm{a}$, etc. refer to the same sample.

Table I

Distribution of chlorophyll-proteins in wild type barley and mutants.

The nomenclature system used for the chlorophyll-proteins is defined in (19). FDMR spectra of chlorophyllproteins in heavy characters are shown in Figure 1.

\begin{tabular}{|c|c|c|c|}
\hline & Photosystem I & Photosystem II & Light-harvesting \\
\hline Wild-type & $\mathrm{Chl}_{\alpha}-\mathbf{P 1}$ & $\left.\mathrm{Chl}_{a}-\mathrm{P} 2^{\mathrm{a}}\right), \mathrm{Chl}_{a}-\mathrm{P} 3$ & $\mathrm{Chl}_{a / b}-\mathrm{P} 1, \mathrm{Chl}_{a / b}-\mathrm{P} 2$ \\
\hline chlorina $-f 2$ & $\mathrm{Chl}_{\alpha}-\mathrm{P} 1$ & $\left.\mathrm{Chl}_{a}-\mathrm{P} 2^{\mathrm{a}}\right), \mathrm{Chl}_{a}-\mathrm{P} 3$ & - \\
\hline viridis $-z b^{63}$ & - & $\left.\mathrm{Ch}_{a}-\mathrm{P} 2^{\mathrm{a}}\right), \mathrm{Ch}_{\alpha}-\mathrm{P3}$ & $\operatorname{Ch}_{a / b}-\mathbf{P 1}, \mathrm{Chl}_{a / b}-\mathbf{P 2}$ \\
\hline
\end{tabular}

a) $\mathrm{Ch}_{a}-\mathrm{P} 2$ is located around photosystem II and may perform a light-focusing function.

\section{Table II}

Fluorescence emission and FDMR parameters of chlorophyll-proteins at $4.2 \mathrm{~K}$.

\begin{tabular}{|c|c|c|c|c|c|c|c|}
\hline \multirow{2}{*}{$\begin{array}{l}\text { Chlorophyll- } \\
\text { protein }\end{array}$} & \multirow{2}{*}{$\left.\lambda_{F}(\mathrm{~nm})^{\mathrm{a}}\right)$} & \multirow{2}{*}{$\left.\lambda_{D}(\mathrm{~nm})^{b}\right)$} & \multicolumn{2}{|c|}{$\begin{array}{c}\text { Microwave frequency } \\
(\mathrm{MHz})\end{array}$} & \multirow{2}{*}{$\begin{array}{c}\text { Sign of } \\
\text { FDMR } \\
\text { signal }\end{array}$} & \multicolumn{2}{|c|}{$\begin{array}{l}\text { Zero field splitting } \\
\text { parameters }\left(\times 10^{-4} \mathrm{~cm}^{-1}\right)\end{array}$} \\
\hline & & & $\mathrm{D}-\mathrm{E}$ & $D+E$ & & $\mathrm{D}$ & $\mathrm{E}$ \\
\hline $\mathrm{Chl}_{a}-\mathrm{Pl}$ & $\left.677 \pm 1,719 \pm 1^{c}\right)$ & $\begin{array}{l}721 \\
679\end{array}$ & $\begin{array}{l}733 \pm 3 \\
754 \pm 4\end{array}$ & $\begin{array}{r}958 \pm 3 \\
1000 \pm 1\end{array}$ & $\begin{array}{l}+ \\
-\end{array}$ & $\begin{array}{l}282 \pm 1 \\
293 \pm 1\end{array}$ & $\begin{array}{l}38 \pm 1 \\
40 \pm 1\end{array}$ \\
\hline $\mathrm{Chl}_{a}-\mathrm{P} 2$ & $\begin{array}{l}\left.676 \pm 2,683^{d}\right) \\
687 \pm 1\end{array}$ & 686 & $739 \pm 6$ & $968 \pm 12$ & + & $285 \pm 3$ & $38 \pm 2$ \\
\hline $\left.\mathrm{Ch}_{a}-\mathrm{P} 3 \mathrm{e}\right)$ & $\sim 670,678 f), 682$ & 686 & $745 \pm 2$ & $975 \pm 2$ & + & $287 \pm 1$ & $38 \pm 1$ \\
\hline $\mathrm{Chl}_{a / b}-\mathrm{PI}$ & 683 & 686 & $755 \pm 11$ & $981 \pm 8$ & - & $290 \pm 3$ & $38 \pm 1$ \\
\hline $\mathrm{Chl}_{a / b}-\mathrm{P} 2$ & $683 \pm 1$ & 686 & $769 \pm 5$ & $991 \pm 8$ & - & $292 \pm 2$ & $38 \pm 1$ \\
\hline
\end{tabular}

a) Wavelengths of fluorescence emission maxima or shoulders. No difference was seen between wild-type and mutants, except where noted.

b) FDMR detection wavelength.

c) Seen in both wild-type and chtorina- $f 2$.

d) Appeared in $\mathrm{Chl}_{a}-\mathrm{P} 2$ from viridis $-2 b^{63}$ but not in chlorina -2 .

e) In $\mathrm{Chl}_{a}-\mathrm{P} 2$ and $\mathrm{Chl}_{\alpha}-\mathrm{P} 3$ there is also an FDMR signal with negative sign (details not shown).

f) Not seen in viridis $-z b^{63}$. 
Table III

Zero field splitting parameters for in vitro photosynthetic pigments at $4.2 \mathrm{~K}^{\mathrm{a}}$ ).

\begin{tabular}{|c|c|c|c|c|}
\hline \multirow{2}{*}{ Compound } & \multirow{2}{*}{ Solvent ${ }^{b}$ ) } & \multirow{2}{*}{$\left.\lambda_{\mathrm{D}}(\mathrm{nm}) \mathcal{C}\right)$} & \multicolumn{2}{|c|}{$\begin{array}{l}\text { Zero field splitting parameters } \\
\qquad\left(\times 10^{-4} \mathrm{~cm}^{-1}\right)\end{array}$} \\
\hline & & & $\mathrm{D}$ & $\mathrm{E}$ \\
\hline $\mathrm{Chl} a \cdot \mathrm{H}_{2} \mathrm{O}$ & $\mathrm{n}-\mathrm{C}_{8}$ & 660 & $305 \pm 3$ & $38 \pm 3$ \\
\hline $\mathrm{Chl} a \cdot 2 \mathrm{pyr}$ & $\mathrm{n}-\mathrm{C}_{8} / \mathrm{pyr}$ & 686 & $283 \pm 5$ & $40 \pm 5$ \\
\hline $\mathrm{Chl} a \cdot 2 \mathrm{H}_{2} \mathrm{O}$ & $\mathrm{n}-\mathrm{C}_{8}$ & 687 & $291 \pm 5$ & $38 \pm 4$ \\
\hline$\left.\left(\mathrm{Chl} a \cdot \mathrm{H}_{2} \mathrm{O}\right)_{2}{ }^{\mathrm{d}}\right)$ & $n-C_{8}$ & 725 & $286 \pm 5$ & $31 \pm 5$ \\
\hline$\left.\left(\mathrm{Chl} a \cdot \mathrm{H}_{2} \mathrm{O}\right)_{n}{ }^{\mathrm{e}}\right)$ & $\mathrm{n}-\mathrm{C}_{8}$ & 750 & $275 \pm 5$ & $35 \pm 6$ \\
\hline$(\mathrm{Chl} a)_{2}$ & Tol & - & $270 \pm 4$ & $40 \pm 2$ \\
\hline $\mathrm{Chl} b \cdot \mathrm{E}_{\mathrm{t}_{1}}$ & $\mathrm{n}-\mathrm{C}_{8} / \mathrm{Et}$ & 644 & $332 \pm 2$ & $33 \pm 2$ \\
\hline $\mathrm{Chl} b \cdot 2 \mathrm{Et}_{1} \cdot \mathrm{Et}_{2}$ & $\mathrm{n}-\mathrm{C}_{8} / \mathrm{Et}$ & 669 & $297 \pm 2$ & $40 \pm 2$ \\
\hline$\left(\mathrm{Chl} b \cdot \mathrm{H}_{2} \mathrm{O}\right)_{2}$ & MP & 700 & $281 \pm 3$ & $31 \pm 3$ \\
\hline \multirow[t]{3}{*}{ Pheophytin $a$} & $\mathrm{n}-\mathrm{C}_{8}$ & 668 & $350 \pm 2$ & $20 \pm 1$ \\
\hline & & 675 & $348 \pm 2$ & $25 \pm 1$ \\
\hline & & 683 & $353 \pm 7$ & $33 \pm 1$ \\
\hline
\end{tabular}

a) Data taken from Kooyman et al. (18, 19) and VAN DER BENT (2).

b) Solvents: $\mathrm{n}-\mathrm{C}_{8}, \mathrm{n}$-octane; pyr, pyridine; Et, ethanol; MP. methylcyclohexane/pentane $(1: 1)$; Tol, toluene.

c) Fluorescence emission detection wavelength.

d) At low temperature an additional water ligand may be attached to each $\mathrm{Mg}$ atom in the dimer.

e) $n \geqslant 2$, but small $(18,19)$.

nected to a Hewlett-Packard variable frequency microwave source (10-1300 $\mathrm{MHz})$, equipped with an Avantek UA 405 microwave amplifier, delivering maximally $\sim 100 \mathrm{~mW}$ microwave power to the sample.

Triplets are generated by irradiating the sample with $400-450 \mathrm{~nm}$ light from a 900 Watt Osram XBO Xenon arc, via the bifurcated quartz light pipe. Emitted fluorescence, collected by the same light pipe passes either through a Balzer B40 interference filter or a Spex Minimate 0.25 $\mathrm{m}$ monochromator and is detected by a RCA 31034 photomultiplier with Peltier cooling.

FDMR spectra are recorded by monitoring the intensity of a selected fluorescence band, while sweeping the frequency of the microwave source. FDMR spectra are accumulated by a signal analyzer, in order to obtain satisfactory signal-to-noise ratio. Typically, 10-50,000 spectra are required, equivalent to a total sweeping time of 3-15 hours per spectrum. Surface-excited fluorescence spectra $(4.2 \mathrm{~K})$ were obtained employing the FDMR spectrometer with microwaves off and scanning the detection monochromator.

\section{RESULTS}

The FDMR spectrum of chlorophyll-proteins isolated from wild-type and mutant barley chloroplasts after SDS solubilisation and polyacrylamide gel electrophoresis have been measured in zero magnetic field at $4.2 \mathrm{~K}$ (Figure $1 \mathrm{a}-\mathrm{e}$ ). In these spectra only the $D-E$ and $D+E$ resonances are observed and not the $2 \mathrm{E}$ resonance. All five different chlorophyll-proteins show a FDMR spectrum. In contrast to FDMR experiments on isolated photosystem I chlorophyll-proteins from the blue-green alga Synechococcus leopoliensis (28) the use of a phosphate buffer during gel electrophoresis was not found essential to obtain FDMR signals.

Table I presents a review of the occurrence and distribution of the chlorophyll-proteins studied. These proteins were also characterised by their fluorescence emission spectra at $4.2 \mathrm{~K}$ 


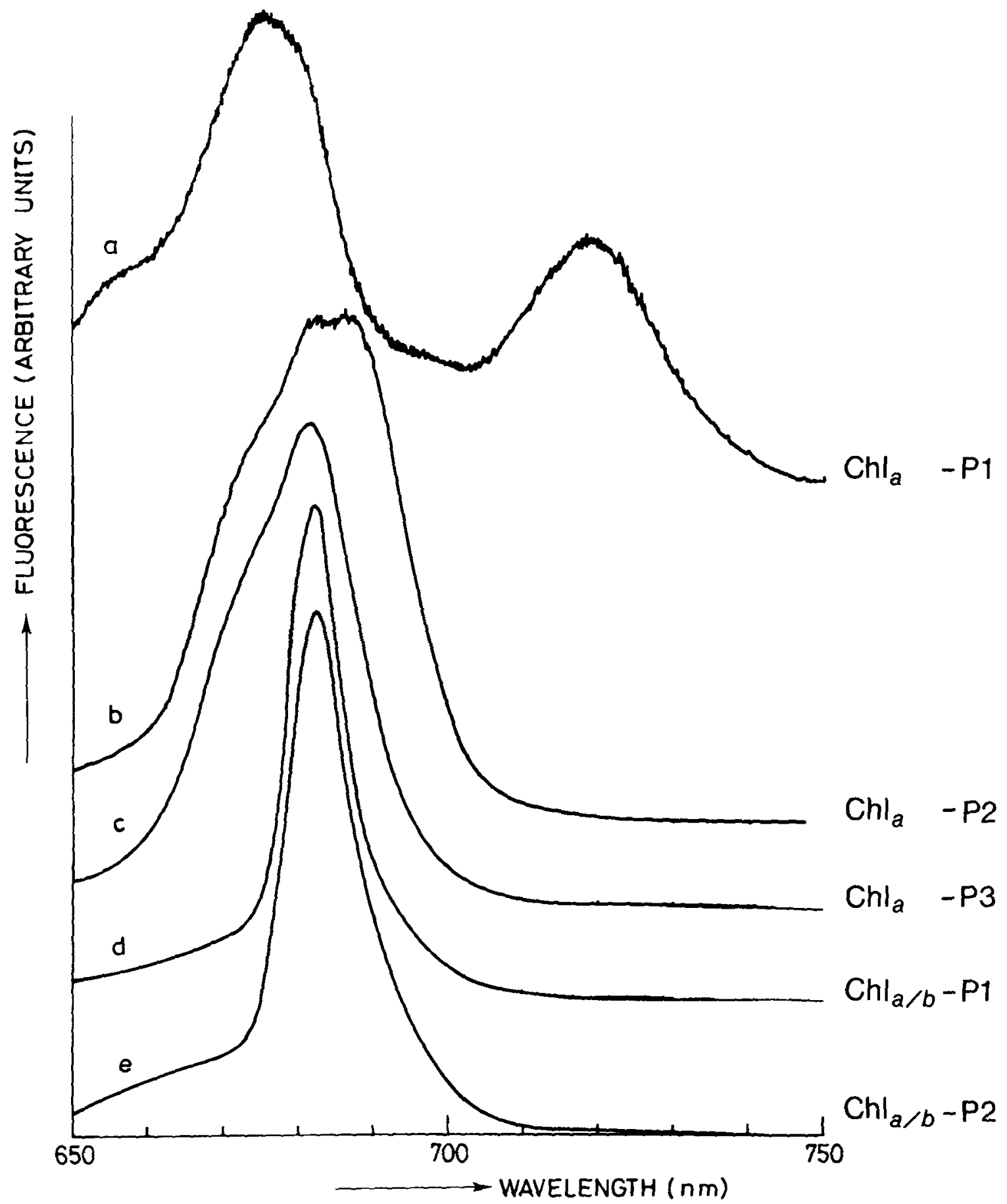

Figure 2. Fluorescence emission spectra of chlorophyll-proteins from barley obtained as indicated in Table I.

The emission spectra were measured in the FDMR spectrometer under the same conditions as for the FDMR spectra, by the use of front surface excitation and with a Spex monochromator (bandwith $5 \mathrm{~nm}$ ) placed between sample and photomultiplier. Spectra a-e refer to the same sample as in Figure 1. 


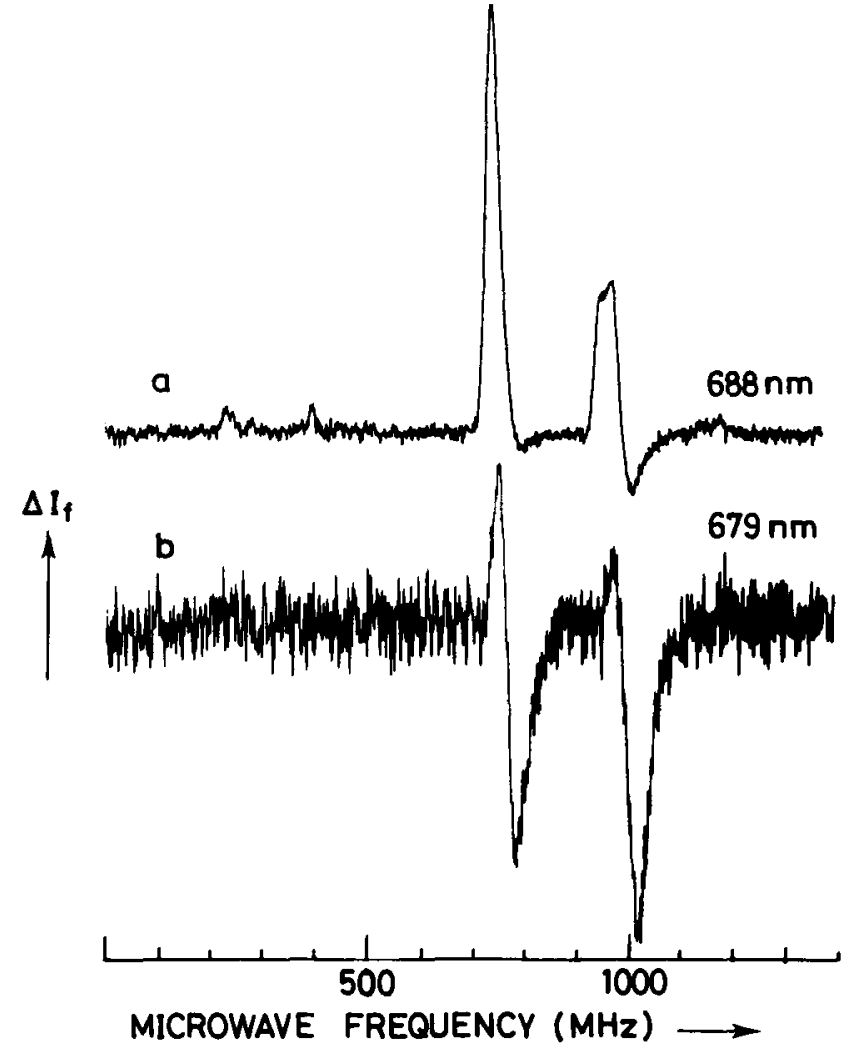

Figure 3. The FDMR spectrum of $\mathrm{Chl}_{a}-\mathrm{P} 2$ protein from barley mutant viridis $-2 b^{63}$ measured in the 688 $\mathrm{nm}(\mathrm{a})$ and 679 (b) fluorescence emission.

Other experimental conditions as in Figure 1.

(Figure 2, Table II). All three proteins containing only Chl $a$ show a FDMR spectrum consisting of a positive signal (increase in fluorescence on resonance with microwaves) but with slightly different $\mathrm{ZFS}$ values (D varies between 282 and $287 \times 10^{-4} \mathrm{~cm}^{-1}$ whilst $\mathrm{E}=38 \times 10^{-4} \mathrm{~cm}^{-1}$ ).

These values correspond closely to those for monomeric $\mathrm{Chl} a$ biligated with pyridine and to those of the chlorophyll dimer $\left(\mathrm{Chl} a \cdot \mathrm{H}_{2} \mathrm{O}\right)_{2}$ (Table III). The emission wavelength at which this triplet state is detected in $\mathrm{Chl}_{a}-\mathrm{Pl}$ is far to the red of that seen for $\mathrm{Chl} a \cdot 2$ pyr and corresponds closely with the emission maximum $(725 \mathrm{~nm})$ for $\left(\mathrm{Chl} a \cdot \mathrm{H}_{2} \mathrm{O}\right)_{2}$.

The ZFS values for the positive FDMR signal in $\mathrm{Chl}_{a}-\mathrm{P} 2$ show a relatively large variation and this is probably attributable to the presence of at least two signals of varying relative proportions close together. This heterogeneity is not very apparent in Figure $1 \mathrm{~b}$ but is more clearly seen by the splitting of the D+E peak in Figure 3a.

Although pheophytin $a$ is considered to be associated with the photosystem II reaction centre (16), and $\mathrm{Chl}_{a}-\mathrm{P} 3$ to contain this reaction centre (20), the FDMR spectrum of $\mathrm{Chl}_{a}-\mathrm{P} 3$ shows no evidence for a triplet state of pheophytin $a$ under the conditions used (see Table III). The remaining FDMR spectra reported in Table II all have a negative sign (decrease in fluorescence on resonance) and show $D$ values $\geqslant 290 \times 10^{-4} \mathrm{~cm}^{-1}$. As expected, the emission maxima and ZFS parameters of the two $\mathrm{Chl}_{a / b^{-}}$ proteins are similar, and the triplet state observed at $686 \mathrm{~nm}$ is that of Chl $a$ and not of $\mathrm{Chl} b$. At shorter wavelengths however, a FDMR spectrum with ZFS values similar to that for Chl $b$ in vitro is observed (29). The ZFS values for $\mathrm{Chl}_{a / b}-\mathrm{P} 1$ and $\mathrm{Chl}_{a / b}-\mathrm{P} 2$ at $686 \mathrm{~nm}$ correspond closely to that for $\mathrm{Chl} a \cdot 2 \mathrm{H}_{2} \mathrm{O}$ (Table III). The $677 \mathrm{~nm}$ emission of $\mathrm{Chl}_{a}$-Pl (Figure 2) is seen in the protein prepared from the chlorina$f 2$ mutant as well as in the wild-type so that it cannot be ascribed to contamination by $\mathrm{Chl}_{a / b^{-}}$ $\mathrm{P} 2$ *** (20).

The significance of the difference in sign of the FDMR spectra for $\mathrm{Chl}_{\alpha}-\mathrm{P}$ and $\mathrm{Chl}_{\alpha / b}-\mathrm{P}$ at the same wavelength (Figure 1) is not clear (5). It is possible that it is simply related to the state of ligation of the chlorophyll molecule, and the nature of the ligands, which can affect the depopulation rates of the three triplet spin-levels (2).

In Figure 3 the FDMR spectrum of $\mathrm{Chl}_{a}-\mathrm{P} 2$ recorded in $688 \mathrm{~nm}$ emission shows that a high signal to noise ratio (about 20:1) can be obtained for chlorophyll-proteins. The difference between the spectra in Figure $3 a$ (for $688 \mathrm{~nm}$ ) and $3 b$ (for $679 \mathrm{~nm}$ ) illustrates the strong wavelength dependence of the FDMR spectrum for this protein. This may allow the use of the fluorescence microwave double resonance technique (see for example ref. 1) to resolve the emission from separate types of chlorophyll $a$ molecules in $\mathrm{Chl}_{a}-\mathrm{P} 2$. The wavelength dependence of FDMR spectra of chlorophyll-proteins appears to be a general phenomenon and is also seen for $\mathrm{Chl}_{a}-\mathrm{Pl}$ (Table II).

Figure 3a demonstrates the presence of three distinct chlorophyll triplet states in a single 
chlorophyll-protein, two with a positive FDMR signal having $Z F S$ values of $D=282, E=37$ and $\mathrm{D}=286, \mathrm{E}=40$ (in units $10^{-4} \mathrm{~cm}^{-1}$ ), and a third signal with a negative sign. In Figure $3 b$ the latter is dominant and this signal can be assigned to a triplet state present in the chlorophyll form emitting at $676 \mathrm{~nm}$ (see also Figure 2 and Table II). It is quite possibie that the other two signals may be similarly correlated each with a chlorophyll form emitting at a specific wavelength.

From Figures $\mathrm{lb}$ and $\mathrm{lc}$ it is seen that $\mathrm{Chl}_{a}-\mathrm{P} 2$ and $\mathrm{Chl}_{a}-\mathrm{P} 3$ show similar FDMR spectra, although the broader $D+E$ peak in Figure $I b$ suggests the heterogeneity of $\mathrm{Ch}_{a}-\mathrm{P} 2$ already mentioned. The fluorescence emission spectrum of $\mathrm{Chl}_{a}-\mathrm{P} 2$ at $4.2 \mathrm{~K}$ is however, distinct from that of $\mathrm{Chl}_{\alpha}-\mathrm{P} 3$ having a $687 \mathrm{~nm}$ emitting component (Figures $2 b$ and $2 c$ ). Therefore these two proteins can be regarded as similar, but nevertheless spectrally distinguishable.

\section{DISCUSSION}

The ability to detect chlorophyll triplet states using the FDMR technique at $4.2 \mathrm{~K}$ in zero magnetic field in welldefined chlorophyll-proteins provides a new and useful means for the study of the structure and function of these building blocks of the photosynthetic apparatus. Already from the experiments reported here we are able to draw several relevant conclusions about the way in which certain chlorophyll molecules interact with protein and with other chlorophyll molecules.

In $\mathrm{Chl}_{a}-\mathrm{Pl}$ derived from photosystem $\mathrm{I}$, the reaction centre $(P 700)$ can be expected to remain in the oxidized form under the conditions of the FDMR experiment - high intensity illumination at $4.2 \mathrm{~K}$ - so that the formation of a chlorophyll triplet at the reaction centre via a radical pair mechanism $(4,14)$ probably can be ruled out (5). The chlorophyll triplet state observed must therefore be located in the photosystem I antenna chlorophyll. The ZFS parameters for the $721 \mathrm{~nm}$ emission of $\mathrm{Chl}_{a}-\mathrm{Pl}$ are rather close to those of monomeric Chl $a \cdot 2$ pyr and also but to a less extent to those of the $\left(\mathrm{Chl} a \cdot \mathrm{H}_{2} \mathrm{O}\right)_{2}$ dimer (see Table III). The observed $\mathrm{Chl}_{a}-\mathrm{P} 1 \mathrm{ZFS}$ values are not however compatible with those of the (Chl $a)_{2}$ dimer or the higher aggregate $\left(\mathrm{Chl} a \cdot \mathrm{H}_{2} \mathrm{O}\right)_{n}$
(Table III). As the wavelength of the emission is far to the red of that of a monomeric form of chlorophyll we must tentatively conclude that the trap in the antenna where the triplet state is located is comprised of an approximately plane parallel chlorophyll $a$ dimer held together by the protein. That the ZFS parameters do not exactly match those of $\left(\mathrm{Chl} a \cdot \mathrm{H}_{2} \mathrm{O}\right)_{2}$ is to be expected as the chlorophylls in the chlorophyll-protein are most probably interacting not with water molecules but rather with protein side-chains containing either oxygen or perhaps nitrogen electron-donating groups. This finding is of interest, in view of the reported coordination of $\mathrm{Mg}$ in bacteriochlorophyll to histidine residues of the protein in the bacteriochlorophyll-protein complex isolated from the green bacteria $P$. aestuarii $2 \mathrm{~K}$ (23). Apparently, therefore the organisation of the chlorophyll molecules in the antenna does not differ in principle from that of the reaction centre, in contrast to the hypothesis of KATZ, Norris and ShIPMAN (15).

It is interesting that the other two chlorophyll $a$-proteins, $\mathrm{Chl}_{a}-\mathrm{P} 2$ and $\mathrm{Chl}_{a}-\mathrm{P} 3$ do not show a long wavelength emission comparable to that seen in $\mathrm{Chl}_{\alpha}-\mathrm{Pl}$. A possible explanation for this is that the chlorophyll molecules in these two proteins are on average further apart and that interaction between chlorophylls is less strong than in $\mathrm{Chl}_{a}-\mathrm{Pl}$. The shorter lifetime for fluorescence from photosystem I at room temperature as compared to photosystem II (27) would then be consistent with a more efficient singlet energy transfer to the photosystem I reaction centre (assuming energy transfer and not trapping to be rate limiting) and a closer average spacing of chlorophyll $a$ molecules in phc'osystem I. In this connection it is of interest that saves of the barley mutant viridis $-z b^{63}$ have a lon $n_{b}$ wavelength emission band even though this mutant lacks photosystem I (12). After SDS polyacrylamide gel electrophoresis none of the chlorophyll-proteins isolated from this mutant retained this emission. Recently it has been observed that the light harvesting chlorophyll a/ $b$-protein 2 isolated and purified by Triton solubilization at $4{ }^{\circ} \mathrm{C}$ had a major emission band at $735 \mathrm{~nm}(10)$. The long wavelength emission of the mutant in situ could thus derive from the chlorophyll $a / b$ proteins.

The SDS solubilized chlorophyll-proteins con- 
taining both chlorophylls $a$ and $b\left(\mathrm{Chl}_{a / b}-\mathrm{P} 1\right.$ $\left.\mathrm{Ch}_{a / b}-\mathrm{P} 2\right)$ did not show a long wavelength emission band. This seems to exclude appreciable Chl $a$ pair interaction. The work of KNOX and vaN MetTer on a similar chlorophyll $a / b$ protein from spinach (17) led to the conclusion that the chlorophyll $b$ molecules were clustered together in the centre of the protein and that the chlorophyll a molecules were placed at the periphery at such a distance from each other that only weak chlorophyll $a$-chlorophyll $a$ interaction is seen. We would like to adapt this model to include relatively strong pairing between chlorophyll $a$ and chlorophyll $b$ molecules, as our work on FDMR reported here and on triplet spin level kinetics of $\mathrm{Chl}_{a / b}-\mathrm{Pl}$ and $-\mathrm{P} 2$ to be reported in a subsequent publication suggest that triplet energy transfer is possible at low temperature from $\mathrm{Chl} b$ to $\mathrm{Chl} a$, a phenomenon known to require short range interaction. A similar suggestion has been made by CLARKE et al. (6). Thus we propose that chlorophyll $a$ and $b$ in these proteins occur in pairs, with the interaction between pairs being relatively weak (29).

The ZFS parameters found for the chlorophyll-proteins and reported in Table II can give us an indication of the nature of the liganding groups binding to the centre $\mathrm{Mg}$ atom in the axial positions in these proteins. For $\mathrm{Chl}_{\alpha}-\mathrm{Pl}$ at $721 \mathrm{~nm}$, and for $\mathrm{Chl}_{a}-\mathrm{P} 2$ and -P3 the experimental ZFS parameters approximately agree with those seen in vitro for $\left(\mathrm{Chl} a \cdot \mathrm{H}_{2} \mathrm{O}\right)_{2}$ and $\mathrm{Chl} a$. 2 pyridine, respectively. This indicates biligation of the chlorophyll and further suggests the imidazole group of histidine as a possible candidate in $\mathrm{Chl}_{a}-\mathrm{P} 2$ and $-\mathrm{P} 3$ and possibly also in $\mathrm{Ch}_{a}-\mathrm{P} 1$, if one considers the differences between the ZFS parameters of $\mathrm{Chl}_{a}-\mathrm{P} 1$ and that for $\left(\mathrm{Chl} a \cdot \mathrm{H}_{2} \mathrm{O}\right)_{2}$. For $\mathrm{Chl}_{a / b}-\mathrm{P} 1$ and $\mathrm{Ch}_{a / b}-\mathrm{P} 2$ the agreement of the observed ZFS parameters with those of $\mathrm{Chl} a \cdot 2 \mathrm{H}_{2} \mathrm{O}$ is very good (Tables II and III), so that in these chlorophyll-proteins the chlorophyll again appears to be biligated, but in this case with water or perhaps oxygen-containing protein side groups.

A feature of the emission spectrum for $\mathrm{Chl}_{a^{-}}$ $\mathrm{Pl}$ is the presence of the $677 \mathrm{~nm}$ band in addition to the long wavelength fluorescence maximum. This shorter wavelength emission could be from chlorophyll molecules which transfer their singlet energy relatively ineffi- ciently to the dimer-like trap referred to above and which emits at $719 \mathrm{~nm}$. The cause for this inefficiency could be: an increase in interchlorophyll distances, a change in relative orientation of the chlorophyll molecules or a decrease in spectral overlap. The observation that the ZFS parameters of the FDMR signal in the $679 \mathrm{~nm}$ emission are different to those in the $721 \mathrm{~nm}$ emission, both with regard to the $\mathrm{D}$ and $E$ values and the sign, suggests in fact the last of the three possibilities, i.e., a change in the bonding of the chlorophyll which leads to shifts in absorbance and emission spectra and so possibly to a reduction in resonance energy transfer.

This communication shows that FDMR spectra together with fluorescence emission spectra of chlorophyll-proteins are able to provide important characteristics of these proteins which should allow us to probe the interaction of chlorophyll with protein side chains and with other chlorophyll molecules to gain an understanding of the way in which the chlorophyll is organised. In addition, these characteristics can be employed to monitor the integrity of the chlorophyll-protein during procedures designed to prepare purified reaction centres from higher plants.

\section{ACKNOWLEDGEMENTS}

The authors are indebted to Drs. G. H. vaN Brakel and L. Benthem for useful discussions, and to INGA Olsen, P. A. DE JAGER and A. van HoEK for technical assistance. This research was supported by the Commission of European Communities, contract ESD-013-DK(G) of the Solar Energy Program.

\section{REFERENCES}

I. Beck, J., G. H Kaiser, I. U. von Schütz \& H. C. Wolf: Optically excited triplet states in the bacteria Rhodopseudomonas sphaeroides „wild type « detected by magnetic resonance in zero field. Biochim. Biophys. Acta 634, 165-173 (1981)

2. BENT, S. J. VAN DER: Interaction of light and microwaves with photosynthetic pigments. $\mathrm{Ph}$. D. Thesis, Wageningen (1977)

3. BENT, S. J. VAN DER, P. A. DE JAGER \& T. J. 
SchaAfsma: Optical detection and electronic simulation of magnetic resonance in zero magnetic field of dihydroporphin in free base. Rev. Sci. Instr. 47, 117-212(1976)

4. Blankenship, R. E., T. J. Schaafsma \& W. W. PARSON: Magnetic field effects on radical pair intermediates in bacterial photosynthesis. Biochim. Biophys. Acta 461, 297-305 (1977)

5. Brakel, G. H. van, T. J. Schaafsma \& J. J. S. VAN RENSEN: Fluorescence detected magnetic resonance (FDMR) of whole algae and the Anacystis nidulans CP-I complex. Isr. J. of Chem., in press. (1981)

6. Clarke, R. H., S. P. Jagannathan \& W. R. LeEnstra: Optical-microwave double resonance spectroscopy of in vivo chlorophyll. Photochem. Photobiol. 32, 805-808 (1980)

7. Clarke, R. H., W. R. Leenstra \& W, G. HaGaR: Observation of a triplet state in chlorophyll protein 668 via optically detected magnetic resonance. FEBS Lett. 99, 207-209 (1979)

8. Dorp, W. G. van, T. J. Schaafsma, M. Soma \& J. H. VAN DER W AALS: Investigation of the lowest triplet state of free base porphin by microwave induced changes in its fluorescence. Chem. Phys. Lett., 21, 221-225 (1973)

9. El-SAyed, M. A.: Phosphorescence-microwave multiple resonance spectroscopy. In: MTP International Review of Science, D. A. Ramsay ed., Butterworths, London, Vol. III pp. 119-153 (1973)

10. Fuad, N., D. A. Day, S. W. Thorne \& I. J. RYRIE: Fluorescence of chlorophyll-protein complexes from higher plants in isolation and upon reconstitution into artificial membranes. Abstracts XIII. Int. Bot. Congress, Sydney, Australia, 1981, p. 223.

11. Geschwind, S., ed., Electron Paramagnetic Resonance, Plenum, New York, (1972)

12. Hiller, R. G., B. L. Møller \& G. HøyerHansen: Characterization of six putative photosystem I mutants in barley. Carlsberg Res. Commun. 45, 315-328 (1980)

13. Hoff, A. J., Govindjee \& J. C. Romisn: Electron spin resonance in zero magnetic field of triplet states of chloroplasts and subchloroplast particles. FEBS Lett., 73, 191-196 (1977)

14. Hoff, A. J., H. Rademaker, R. van Grondelle \& L. N. M. Dursens: On the magnetic field dependence of the yield of the triplet state in reaction centers of photosynthetic bacteria. Biochim. Biophys. Acta 460, 547-554 (1977)

15. Katz, J. J., J. R. Norris \& L. L. Shipman: Models for reaction center and antenna chlorophyll. Brookhaven Symp. Biol. 28, 16-55 (1977)

16. Klimov, V. V., E. Dolan \& B. Ke: EPR properties of an intermediary acceptor (pheophytin) in P. S.-II reaction centers at low temperature. FEBS Lett. 112, 97-100 (1980)

17. Knox R. S. \& R. L. van MetTer: Fluorescence of light-harvesting chlorophyll a/b-protein complexes: Implications for the photosynthetic unit. In: Chlorophyll organisation and Energy Transfer in Photosynthesis, Ciba Found. Symp. 61, pp. 177-190. Elsevier, Amsterdam (1979)

18. Kooyman, R. P. H.: Complexes and aggregates of chlorophylls. Ph. D. Thesis, Wageningen (1980)

19. Kooyman, R. P. H., T. J. Schaafsma \& J. F. KLEIBEUKER: Fluorescence spectra and zero field magnetic resonance of chlorophyll-a-water complexes. Photochem. Photobiol. 26, 235-240 (1970)

20. Machold, O., D. J. Simpson \& B. L. Møller: Chlorophyll-proteins of thylakoids from wild type and mutants of barley (Hordeum vulgare L.). Carlsberg Res. Commun. 44, 235-254 (1979)

21. Markwell, J. P., J. P. Thornber \& R. T. BoGgs: Higher plant chloroplast: Evidence that all the chlorophyll exists as chlorophyll-protein complexes. Proc. nat. Acad. Sci. USA 76, $1233-$ 1235 (1979)

22. Mau, A. W. H. \& M. Puza: Phosphorescence of chlorophylls. Photochem. Photobiol. 25, 601603 (1977)

23. Olson, J. M.: Bacteriochlorophyll-proteins from green bacteria. In: The Photosynthetic Bacteria, R. K. Clayton and W. R. Sistrom eds., Plenum, New York, Chapter 8 (1978)

24. SchaAfsma, T. J.: ODMR of the chlorophylls in vitro and in vivo. In: ODMR Spectroscopy: Techniques and Application to Biophysical Systems, R. H. Clarke ed., Wiley, New York, Chapter 8, in press (1981)

25. Schaafsma, T. J.: The study of the electronic structure of porphyrin molecules in solid matrices by optical and magnetic resonance spectroscopy. Proc. Fourth Int. Sem. Energy Transfer in Condensed Matter, Prague, June 30-July 3, Czechoslovakia (1981)

26. Schmidt, J. \& J. H. VAN DER WaAls: Optical detection of zero field transitions in phosphorescent triplet states. Chem. Phys. Lett. 2, 640642 (1968)

27. Searle, G. F. W., J. Barber, L. Harris, G. Porter \& C. J. Tredwell: Picosecond laser study of fluorescence life times in spinach chloroplast photosystem I and photosystem II preparations. Biochim. Biophys. Acta 459, 390401 (1977)

28. Searle G. F. W., G. H. van Brakel, W. F. J. 
Vermaas, a. van Hoek \& T. J. Schaafsma: Chlorophyll triplets and energy transfer in isolated P.S.-I chlorophyll proteins from bluegreen algae. Proc. 5th. Int. congress on Photosynthesis, Halkidiki, Greece, in press, (1980)

29. Searle, G. F. W., R. B. M. Koenorst \& T. J. SchaAfsma: Fluorescence detected magnetic resonance of isolated chlorophyll-proteins containing chlorophyll $a$ and $b$ : energy transfer studies. Proc. Fourth Int. Sem. Energy Transfer in Condensed Matter, Prague, June 30th-July 3rd, Czechoslovakia (1981)
30. Simpson, D. J. \& D. von Wettstein: Macromolecular physiology of plastids. XIV. Viridis mutants in barley: genetic, fluorescopic and ultrastructural characterisations. Carlsberg Res. Commun. 45, 283-314 (1980)

31. WaAls, J. H. van der \& M. S. de Groot: Magnetic interactions related to phosphorescence. In: The Triplet State, A. B. Zahlan ed., The University Press, Cambridge, pp. 101-133 (1967) 